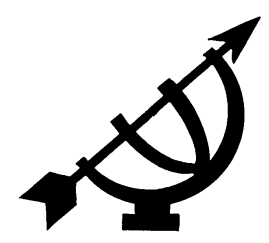

\title{
The importance and significance of
} peace studies with special reference to South Africa's political-security role in Africa

Theo Neethling Department of Political Science

Faculty of Military Science (Military Academy)

University of Stellenbosch

SALDANHA

E-mail: theon@ma2.sun.ac.za

\begin{abstract}
The importance and significance of peace studies with special reference to South Africa's political-security role in Africa

The origins of peace studies as an academic field of inquiry could be traced to the late 1940s and the field has been developing considerably since then. Currently, scholars at various tertiary institutions over the world are involved in using their academic skills to educate students about the causes of wars and violent conflict while pointing out various alternatives to these phenomena. Peace studies in the South African and broader African context are certainly of great significance and importance. After all, the gripping and devastating violence that manifested in African countries such as Liberia, Sierra Leone, Sudan, Burundi, Rwanda, the DRC, Somalia, Angola, the Comoros and many other conflict-stricken areas warrant scholarly attention with a view to better understanding the causes, dynamics and effects of such conflict. By means of this understanding the conflict could be addressed through mechanisms of conflict resolution and peace building could be promoted. Furthermore, the South African Government's progressive military involvement in international peace missions in recent years is far more than an issue of mere military concern. It is a matter of great political interest and significance. Being supportive of the need for peace studies in the curricula of South African universities (and African universities in
\end{abstract}


general), this article argues that South African students should be exposed to a rich and comprehensive literature on the search for international peace and security; of how to understand and deal with the causes of large-scale conflict and violence; and how these could be curtailed and resolved literature which informs scholarly discussions and research in many centres and places of education, training and peace building.

\section{Opsomming}

\section{Die belangrikheid en betekenis van vredestudies met spesifieke verwysing na Suid-Afrika se politieke en veiligheidsrol in Afrika}

Die oorsprong van vredestudies van die twintigste eeu as 'n akademiese ondersoekveld kan teruggespeur word na die laat veertigerjare en het sedertdien aansienlike ontwikkeling deurgemaak. Tans is verskeie vakkundiges aan 'n verskeidenheid tersiêre instellings oor die wêreld heen betrokke by die aanwending van hulle akademiese vaardighede in die opvoeding van studente aangaande die oorsake van oorloë en gewapende konflik, asook om alternatiewe vir dié verskynsels aan die hand te doen. Vredestudies in die Suid-Afrikaanse en breë Afrikakonteks is sekerlik van groot betekenis en belangrikheid. Per slot van sake noodsaak die beklemmende en vernietigende gewelddadige manifestasie van konflik in Afrikastate soos Liberië, Sierra Leone, Soedan, Burundi, Rwanda, die DRK, Somalië, Angola, die Comores en vele ander konflikgeteisterde gebiede vakkundige aandag, met die doel om die oorsake, dinamiek en gevolge van sodanige konflikte beter te verstaan. 'n Beter begrip daarvan help ook pogings bevorder om sodanige konflikte deur middel van meganismes van konflikresolusie en vredesbou die hoof te bied. Verder is die Suid-Afrikaanse regering se toenemende militêre betrokkenheid in onlangse jare by internasionale vredesendings méér as net van militêre belang. Dit is 'n saak van groot politieke belang en betekenis. Vanuit 'n vertrekpunt van ondersteuning vir die noodsaak van vredestudies in die leerplanne van Suid-Afrikaanse universiteite (en Afrikauniversiteite in die algemeen), word in dié artikel aangevoer dat Suid-Afrikaanse studente blootgestel behoort te word aan die ryk en omvangryke literatuur aangaande die soeke na internasionale vrede en veiligheid, hoe om die oorsake van grootskaalse konflik en geweld te verstaan en daarmee te werk te gaan, en hoe dit bekamp en opgelos kan word - literatuur wat vakkundige besprekings en navorsing in baie sentra en plekke van opvoeding, opleiding en vredesbou onderlê. 


\section{Introduction}

Africa is known as a continent that is steeped in armed conflict and instability, the sources of which are both diverse and endemic. The most violent and devastating conflicts have notably been intra-state in nature: conflicts with considerable peacekeeping consequences for regional and international role-players. Such conflicts have led to despair, destitution, poverty, disease, refugee problems and internally displaced persons. It is also commonly known that armed conflicts on the African continent have seriously undermined the attainment of development, security and democratic consolidation. Without stability there will be little chance for economic development and growth and thus the marginalisation of Africa in the international community will continue. In short, there is a pressing need for African and other role-players to register greater progress in the need to address and resolve the conflicts on the continent and to strengthen the foundation for durable peace and economic development.

At an international conference held in Potchefstroom in March 2006, Voices of Africa - Voices for Peace, one of the participants described the dilemma of the African continent as follows (NWU, 2006):

Africa is plagued by numerous political, social and economic issues that are dramatically intensified by civil wars and interstate conflicts on the continent. These conflicts are directly responsible for the economic chaos that prevails in the war-torn countries. It is therefore crucial that these wars be stopped.

Towards the end of the conference the following resolutions were tabled and endorsed by the participants (NWU, 2006):

- Violence in any form is condemned, irrespective of religious or other differences between people, and all conference-goers committed themselves to the promotion of peace.

- Violence could not be ascribed to just a few (economic and political) causes; violence is a complex problem and academics should clearly identify its various causes and approach it accordingly.

- Despite the fact that an academic approach or attempt cannot solve all problems, it can still provide valuable knowledge and skills; peace studies should therefore form part of universities' curricula. 
- Different strategies were identified during the conference for preventing and resolving violence and conflict: from the most straightforward and basic (language, education of children, etcetera) to the greater need for more just communities.

- Due to the fact that universities do not focus enough on peace studies, as well as the fact that there are relatively few organisms that specifically concern themselves with peace creation, the conference called on all persons involved to strive for closer cooperation and to support each other purposefully.

Of course, conflict as a phenomenon is not limited to Africa and it is a natural part of interaction between people across the board. However, conflict may all too easily escalate into armed conflict or large-scale violence. Put differently, members of a particular group may turn to violent action to resolve their differences with another group - and Africa has experienced many different types of conflict in the last forty years (Olonisakin, 2002:231-232).

Moreover, it is a truism that the undertaking of peace initiatives in Africa is by no means an easy task. Conflict in Africa poses a major challenge to United Nations (UN) efforts designed to ensure global peace, prosperity and human rights for all. In fact, the African continent has exercised a critical impact on defining the limits and possibilities of the post-Cold War order and the place of the UN (which has the ultimate responsibility for maintaining peace and security in the world) in this framework (Clapham, 1998:1).

Against this background the significance and importance of peace studies in the African context is obviously of great interest, significance and importance. Internationally, educators in various settings and locations contend that students should be taught about peace. In the words of Finley (2003:274): "If we wish to transform our world into a more peaceful place, including all that the notion of positive peace entails, it seems as though one logical place to start is the classroom." In Political Sciences, more specifically in the subdiscipline of International Relations (sometimes referred to as International Politics), peace studies or peace research was institutionalised as a field of scholarly inquiry in its own right as far back as the onset of World War II. Although strongly institutionalised in International Relations and the focus area of many International Relations scholars over the world, peace studies today are not confined to scholarship in International Relations, but rather a multidisciplinary scholarly enterprise with a distinct focus on conflict and violence (Lawson, 2003:50). 
Being supportive of the need for peace studies in the curricula of South African universities (and African universities in general), the aim of this article is to reflect on and discuss the importance and significance of peace studies as a field of scholarly inquiry with special reference to the South African context. Specifically, this will be dealt with from a Political Sciences point of view. To address and analyse the aforementioned, this article will firstly address the phenomenon of violent conflict in Africa. Having addressed this, the focus will shift to peace studies as a distinct focus area of scholarship in International Relations. Against this background, scholarship in peace studies in the South African scholarly community will be assessed. Finally, the article will reflect on the importance and relevance of peace studies in terms of contemporary South African foreign policy with specific reference to the country's commitment to conflict resolution and peacekeeping on the African continent.

\section{Background: conflict in Africa}

Kirsten (2006:2) points out that Africa's recent history since the era of independence, and after its integration in the international community as a large group of 53 independent states, has been characterised by numerous international and civil wars, and also civil strife of various kinds. This has contributed to a significant extent to Africa being the poorest continent in the current-day international political economy. Kirsten (2006:6) furthermore quotes former US Secretary of State, Henry Kissinger, who stated that it is mainly due to wars and the consequences thereof that Africa is regarded as a tragedy in the modern world.

Conflict in Africa is, of course, multifaceted and wide-ranging. Olonisakin (2002:232-237) identifies the following sources and types of conflict in Africa: colonialism and wars of national liberation; postindependence inter-state conflicts; intra-state conflicts; Cold War (ideologically) assisted conflicts; and post-Cold War conflicts. Lodge (1998:1) similarly provides a very useful typology of Africa's armed conflict under seven headings:

- Ethnic competition for control of the state: The wars in Burundi and Rwanda were two of the most acute examples of struggles for ascendancy between two ethnic groups, namely the Hutu and Tutsi groups. In 1993, up to 100000 people died in fighting which date from the immediate post-colonial period and which originated during the Belgian colonial administration. Shortly after, in 1994, close to a million people (mostly estimated 
at a figure of 800 000) died in Rwanda as a result of genocidal massacres on Tutsi communities by the Hutu army (Lodge, 1998:1).

- Regional or secessionist rebellions: One of the most protracted and bloody conflicts in Africa is the civil war in Sudan, which has a history that began in 1957. The modern phase of war was prompted by the decision in 1981 to disband the regional administration which had governed the southern part of the country in which, in contrast to the Muslim north, the six million inhabitants are mainly Christian or animist, and in which British imperial policy had accentuated local perceptions of colonial style domination by the North (Lodge, 1998:2). Nigeria also went through a bloody civil war from 1967 to 1970 when Biafra sought to secede from the central Nigerian state. Likewise, the people of Western Sahara desired to create their own independent state from Morocco (Olonisakin, 2002:233). In recent years, the fourisland state of Comoros was rocked by instability as a result of two islands that demanded their independence from the Federal Republic. The two islands, Anjouan and Moheli, wanted either a return to French rule, or the status of micro-states in association with France (IRIN, 2006).

- Continuation of liberation conflicts: Probably the most severe and extensive conflict has been the more than three decades long civil war in Angola between the UNITA rebel group and the Angolan government. The protracted character of the Angolan war has been attributable inter alia to the complexities of a liberation struggle which featured popularly-based movements competing for ascendancy (Lodge, 1998:2). This conflict was to a large measure fuelled by super power involvement (Olonisakin, 2002:237), while natural resources, specifically the spatial distribution of Angolan oil and diamonds, also significantly influenced the course of the conflict since the 1990s (Le Billon, 2006:138).

- Fundamentalist religious opposition to secular authority: Militarised Islamic opposition has been active in several North African countries in recent times. In Algeria for instance, 150000 people have lost their lives as a consequence of the civil war which began in February 1992 after the declaration of a state of emergency by the government. Another example is the protracted conflict and consequent loss of lives in northern Uganda where the Lord's Resistance Army, a militant nominally Christian political organisation, has been seeking to establish in Kampala a 
government said to be based on the Ten Commandments (Lodge, 1998:3).

- Warfare arising from state degeneration or state collapse: The conflicts in Liberia, Sierra Leone and the Democratic Republic of the Congo (DRC) each developed in countries where state institutions had been weakened by decades of predatory corrupt government and elite factionalism (Lodge, 1998:3). Those who were unable to seek redress from a court of law, since the central authority controlled all the institutions that could address their grievances, resorted to armed conflict in order to right the wrongs they believed had been committed against them (Olonisakin, 2002:237). These conflicts all generated substantial death tolls with considerable regional instability.

- Protracted conflict with politicised militaries: The case of Lesotho provides a typical example where traditional affinity between the army and politicians have helped to ensure hostility between military commanders and the government, as well as intensifying factionalism within command structures. The resulting tensions generated a succession of violent mutinies in the 1990s (Lodge, 1998:5). Likewise, the current conflict in Côte d'Ivoire can be traced to a vexatious unwillingness to seize on numerous opportunities to transform and reorient the security apparatus. It relates to problematic civil-military relations and, what is referred to by N'Diaye (2004:89-90) as "coup vulnerability". Schraeder (2004:202) states that "African militaries emerged from the shadows of obscurity during the 1950s to become one of the most important institutional actors in African politics and societies". The primary means for African military staff to achieve power and influence over the respective political systems was the military coup d'état; i.e. the sudden and illegal overthrow of a civilian government, by a portion of the state's armed forces. Even in cases where military leaders led their troops back to the barracks after turning power to civilian authorities, many military leaders maintained - and often enhanced - their newfound levels of political influence.

- Border disputes: Disputes over the precise locations of colonial frontiers have, for instance, assumed a military dimension in the cases of Nigeria and Cameroon; and Botswana and Namibia (Lodge, 1998:5). Furthermore the UN, the former Organisation of African Unity (OAU), the African Union (AU) and individual Western countries tried to mediate the conflict between Eritrea and Ethiopia since 1998, but sporadic conflict between the two 
countries prevailed and still poses a challenge to the international peacekeeping regime (UN, 2006). These conflicts resulted from problems created by colonialism and basically generated conflicts between neighbouring states (Olonisakin, 2002:233).

In view of the above, it should be clear that the problem of violent internal conflict in Africa is acute. It has been judged to be the most war prone region in the international community in recent history. Africa's conflicts pose particular conflict management challenges as engagement in peacekeeping operations in civil conflicts is inherently more invidious and usually also more hazardous than the simple interposition of a peacekeeping force between states that have already agreed on a settlement. Moreover, African civil wars tend to be immensely intense and intractable, and spill across national boundaries and draw in surrounding states (Jackson, 2002:30-31), as specifically witnessed in the Africa's Great Lakes area and West Africa concerning the conflicts in the DRC and Sierra Leone respectively. The continent's conflicts have also involved a high measure of multiple interventions from external parties. In fact, Africa has seen the highest rate of external intervention in conflicts, including the turbulent Middle East (Jackson, 2002:32).

The authoritative African specialist, Christopher Clapham (1998:1), contends that Africa has by far been the most important regional setting for the peacekeeping operations of the UN. Of the peacekeeping operations established by the UN since the end of the Cold War, nearly half have been in Africa. In the words of Clapham, (1998:1, 5):

For better or for worse, Africa has had a critical impact in defining the limits and possibilities of the post-Cold War global order, and the place of the United Nations within it ... peacekeepers in Africa have been plunged into the most intractable problems involved in attempting to maintain some kind of order in one of the world's most violent and unstable continents.

On the positive side, in cases where peacekeeping operations do take place, there is now - more than ever before - a substantial body of knowledge and scholarship, which could and should be used to enhance the prospects for relative success, in approaching the always difficult and challenging task of trying to promote peace and security on the African continent and further afield. Much of this could be attributed to research and scholarship in the field of peace studies, which will be outlined and discussed in the section below. 


\section{Peace studies as a distinct area of scholarly inquiry}

The origins of peace studies as an academic field of inquiry could be traced to the late 1940s and the field has been developing steadily since then (Steinberg, 2004:1). It is in the realm of peace studies or peace research that many International Relations scholars have engaged themselves who have been motivated by strong moral concerns. Although heavily reliant on empirical research methods, these scholars tend to work within the Idealist paradigm in International Relations in terms of considering and understanding world events. Idealism, a long-standing and very prominent school of thought in International Relations since the end of World War II, contend that wars occur as a result of misunderstandings, ignorance and stupidity and that they could, therefore, be prevented if only leaders and citizens would consider the probable, if unintended, consequences of their actions. To this end, Idealism as a paradigm became known as a school of thought in International Relations which focused on how to achieve the best and a capacity to be good; meaning that international relations should revolve around creating the right circumstances and institutions in which people's talents and propensity for the good may blossom (Nel, 1999:58).

Idealism, by the way, has long provided an important critique of the Realist school of thought in International Relations, which include a rather pessimistic view of human nature; one that feeds into a statecentric theory of power politics and the struggle for survival in a dangerous and irredeemably anarchic world (Lawson, 2003:79). Thus Realism is a theory which purports that states are essentially selfish actors that seek to maximise their own interests - making conflict an inevitable and inherent part of international relations. Realists are, therefore, sceptical about any emphasis on the role of morality in international relations for they simply believe that the nature of the international system is such that it does not encourage states to behave in terms of moral principles or the common good of the international community ( $\mathrm{Nel}, 1999: 56)$.

In contrast, peace studies arose as a field in International Relations devoted to understanding the causes of war by means of systematic analyses of the historical experiences of armed conflict and war. The causes of war remain to this day of fundamental importance to peace researchers (Wallensteen, 2002:6). Peace researchers generally agree that violence is the most extreme manifestation of conflict and that a valid self-sustaining condition of peace should begin by an understanding of conflict per se (Evans \& Newnham, 2003:425). Moreover, since armed conflict and war are among the 
most destructive phenomena that one human group could inflict on another, the projects within the peace studies fraternity commonly aim at understanding why such conflicts occur and how they could be terminated (Wallensteen, 2002:17). Furthermore, what also makes this kind of scholarship a distinct area of scholarly inquiry in Political Sciences - and in other disciplines too - is that scholarship in peace studies places peace, violence and non-violence, conflict and conflict transformation at the centre of its study, instead of generally regarding these issues and phenomena as important aspects of human social life. They explicitly regard certain conditions as problematic and commit themselves both to understanding and changing certain conditions (Anon., 2006).

In view of the above, peace studies seek to improve the present and future prospects of peace. As such peace studies are not a valuefree branch of inquiry; indeed values intrude into peace research in two distinctive ways. Firstly, peace researchers are philosophically committed to the view that peace is both attainable and desirable. Secondly, by conducting peace research it is believed that the goal of peace may be moved closer to realisation. In this way peace studies could be viewed as an applied study, rather than the pursuit of knowledge for its own sake (Evans \& Newnham, 2003:424).

Although many of those engaged in peace studies have been strongly motivated by moral concerns, Lawson (2003:63) points out that their methods have been strongly positivist in nature. In other words such scholars do not discard many of the propositions of the behaviouralist approach in International Relations. ${ }^{1}$ Holsti (1983:12) likewise points out that the objective of peace research is clearly normative, namely devising ways to control processes leading to violence, but that this is done on the basis of techniques that are scientific and systematic.

Holsti (1983:120) furthermore points out that this type of scholarship (peace studies) has earned itself a rather unfortunate image as fuzzy-minded, naïve intellectuals pontificating from their ivory towers about ways to secure everlasting peace. Conversely, some proponents of this scholarship have often complained that

... while students generally understand what is meant by the concept of warfare, they often 'have very hazy ideas about the

1 This approach is strongly empirically based. See for instance Journal of Peace Research of the International Peace Research Institute in Oslo. 
nature of peace'... few (people) seem to have considered that the messages we send, via the media as well as the school curriculum, processes and structures, teach kids warfare is what history is all about (Finley, 2003:150).

Be that as it may, work undertaken in the field of peace studies has indeed made important contributions to the understanding of problems such as

- processes leading to war;

- the escalation of violence;

- the relationship between individual personality characteristics and the phenomena of bigotry, prejudice, and national hostility;

- the economic consequences of disarmament and arms control programmes; and

- the sources of public attitudes toward foreign countries and alien cultures.

It has already been pointed out that many scholars of peace studies are from the Political Sciences fraternity, specifically International Relations, but many of the topics researched by peace researchers are administratively and intellectually embraced in other disciplines as well, such as psychology, philosophy, theology, history, sociology and anthropology (Wallensteen, 2002:6; Anon., 2006). In practice, a plethora of research centres, institutes, organisations and networks in North America, Europe and Asia (especially Japan) are today actively involved in the conduct and promotion of peace research. Also, the existence of a dynamic International Peace Research Association, with over 1300 members from some 90 countries and links with more than 200 research organisations, exemplifies the measure of emphasis placed on peace research as a distinct field of inquiry. Today, IPRA has five regional associations: the Asia-Pacific Peace Research Association; the Africa Peace Research and Education Association; the European Peace Research Association; the Latin American Peace Research Association and the Peace and Justice Association in North America. The Association's bi-annual conference is a major international event, usually involving participants from more than 50 countries. IPRA also sponsors journals of the highest quality in peace research and peace education. Specifically, the International Journal of Peace Studies provides a peer reviewed outlet for high-quality scholarly input (IPRA, 2006). 
One typical example of a current-day research institute that is involved in peace research, is the internationally acclaimed Stockholm International Peace Research Institute (SIPRI). The task of SIPRI is set to

conduct research on questions of conflict and co-operation of importance for international peace and security, with the aim of contributing to an understanding of the conditions for peaceful solutions of international conflicts and for stable peace (SIPRI, 2003).

In this respect, SIPRI has become famous for its annual SIPRI Yearbooks - highly acclaimed and comprehensive data-bases, analyses and assessments with regard to international security and conflict, military spending and armaments; as well as nonproliferation, arms control and disarmament.

In the 1980's peace study programmes saw a huge expansion on campuses as a result of a growing alarm about the production and threatened use of nuclear weapons (Harris, Fisk \& Rank, 1998). But even before that the 1962 Cuban missile crisis and the concern that the policies of strategic deterrence had brought the world to the brink of nuclear annihilation, accelerated the growth of peace studies in academic frameworks in the Western world (Steinberg, 2004:2-3). Today, students in many parts of the world can now major in peace studies at a variety of universities and other tertiary institutions, although many only take a single course. The Department of Peace Studies at the University of Bradford in the north of England is, for instance, one of the largest and most comprehensive of its kind in the world, offering B.A., M.A., M.Phil. and Ph.D. degrees (Harris, Fisk \& Rank, 1998). The Department is also home to a number of research centres, namely the Centre for Conflict Resolution, the Bradford Disarmament Research Centre, the African Centre for Peace and Conflict Studies, the International Centre for Participation Studies, and the Research Unit in South East European Studies (University of Bradford, 2006).

Finally, it needs to be stated that conflict resolution has especially taken on a quite significant and central meaning in peace studies and the literature in this field has grown considerably. As an area of special focus, conflict resolution deals with situations where conflicting parties enter into an agreement that solves their central incompatibilities, accept each other's continued existence as parties and cease all violent action against each other. In a broader context, this coincides with projects within the peace studies community that 
are all aimed at understanding why conflicts occur, or how they can be terminated (Wallensteen, 2002:17).

This begs the question: what do South African scholars and researchers contribute to the body of knowledge - specifically with regard to understanding the peculiar challenges of the African context?

\section{South African scholarship and research endeavours}

An analysis of South African scholarship reveals that there are indeed major contributions by South African researchers to the body of knowledge in the field of peace studies, specifically with regard to understanding conflicts on the African continent and fostering processes of peace building in conflict-stricken African states. Two fairly large research centres, both non-governmental organisations, merit specific mention: namely the Gauteng-based Institute for Security Studies (ISS) and the KwaZulu-Natal-based African Centre for the Constructive Resolution of Disputes (ACCORD, 2006b).

ACCORD describes itself as an international civil society organisation operating throughout Africa to bring appropriate African solutions to the challenges posed by conflict on the African continent. As far as research publications are concerned, it produces an accredited scholarly journal, African Journal on Conflict Resolution. This is complemented by Conflict Trends, a more popular magazine-type journal, that reports and analyses trends in current and emerging conflicts on the African continent (ACCORD, 2006b).

One of ACCORD's programmes concerns peace and security in Africa, and in surveying this landscape, ACCORD's Peace and Security Unit attempts to carefully monitor the developments across the continent. Most of the activities undertaken by the Unit are structured along the lines of training, research, advocacy and policy development. More specifically, the Unit conducts peacekeeping training for military and civilian personnel who are possible candidates for deployment in international peace missions; provides contributions to policy debates around collective security in Southern Africa, and undertakes research to better understand peacekeeping concepts and lessons learned for regional relevance. ACCORD's Peace and Security Unit has responded to peace and security issues on the continent through its work in a number of programmes and projects. These include the Training for Peace in Africa Project, funded by the Norwegian Ministry of Foreign Affairs; the African 
Civil-Military Co-ordination Programme, funded by the Finish Ministry of Foreign Affairs; and a short-term Book Project with the UN University on the "Unintended Consequences of Peacekeeping" (ACCORD, 2006a). In this regard, ACCORD claims to "... bring African solutions to African problems" and "[w]hile attempting to keep abreast of international trends, we are very conscious also of our African perspective. We make a point of using African methodologies, resources and experience". In the field of training, where ACCORD is especially active, it offers a range of public courses in conflict management theory and practice, and in mediation and negotiation. More than 12000 people have been trained throughout Africa since 1992 (ACCORD, 2006b).

Apart from ACCORD, the ISS is currently one of the largest strategic studies/peace research institutes in Africa. Starting with a small core in 1991, the organisation has grown both in size and orientation. During the past decade the ISS has focused its mission and research activities mainly on the concept of human security - which is very relevant to peace studies. Many of the world's poorest states have experienced violent conflict in the past decades and it is today widely accepted that contemporary armed conflicts require sustained efforts that address not only the military dimensions of conflicts, but also the political, humanitarian, economic and social dimensions of conflicts.

The ISS's concern with human security is based on the linkage between security and development (ISS, 2006a). Explaining this linkage, De Coning (2004:42) points out that extensive research undertaken over a considerable period suggests that about half of all peace agreements fail in the first five years after their conclusion. This could often be blamed on protagonists in conflicts, because they frequently agree to peace agreements for tactical reasons without being firmly committed to a long-term peace process. Also, international role-players are sometimes to be blamed for pressurising protagonists to sign peace agreements when they are aware that the agreements are likely to fail because of unrealistic time frames, or as a result of the root-causes of the conflict not being addressed. Therefore, for some years there has been a growing concern with and emphasis on the necessity of linking security and development to achieve meaningful peace, and pursuing this by means of special peace building measures. Lying at the nexus of development and security, peace building requires a readiness to make a difference on the ground in preventing conflicts or establishing the conditions for a return to sustainable peace. 
Peace building essentially implies the consolidation and promotion of peace and the building of trust in the aftermath of a conflict to prevent a relapse into conflict or war. To this end, a range of reforms throughout the international system has taken place to facilitate peace building endeavours.

Against this background, the ISS's point of departure is that without security and stability, development, growth and prosperity are unachievable. Organisationally, the ISS is divided into the following broad research areas (ISS, 2006a):

- arms management;

- African security analysis;

- peace missions;

- organised crime, corruption, money laundering and terrorism;

- security sector transformation; and

- human security in Southern Africa.

The ISS is well funded and depends on a host of internal and external donors, such as the following governments and institutions (ISS, 2006b):

- Australian Agency for International Development;

- British High Commission;

- Canadian International Development Agency;

- Danish Development Agency;

- Embassy of the United States of America;

- European Community;

- Ford Foundation;

- Government of Sweden;

- Government of Switzerland;

- Hans Seidel Foundation of Germany;

- New York International Peace Academy;

- Norwegian Agency for Development Co-operation; 
- Norwegian Institute of International Affairs;

- Rockefeller Brothers Fund;

- Royal Netherlands Government;

- United Nations;

- US Agency for International Development.

By its own definition, the ISS is an applied policy research organisation or think-tank. Therefore, it focuses on the impact of research on policy and upon public information and dissemination activities. This is achieved through sustained research and the dissemination of information relating to individual, national, regional and international security (ISS, 2006a). Since its inception, the ISS has facilitated and has made some significant and numerous contributions through a range of regular publications, such as its flagship publication, African Security Review, all of which are distributed to academics, universities and institutes in South Africa and abroad. In addition, the hosting of regular conferences is an important part of activities organised by the ISS. Apart from larger conferences, the ISS also runs a series of monthly seminars (ISS, 2006b). These sessions provide the opportunity for informed discussion around topics ranging from the future of the DRC and the Great Lakes area to the conflicts in Sudan and other conflict-stricken African states, as well as some other issues relating to African security.

It should be noted is that human security thinking is quite evident in South Africa's resort to military power in the post-1994 period.

One way in which South Africa has 'operationalised' human security is by establishing a long-term commitment of its armed forces (and other agencies) to peace operations ... It has gone the 'extra mile' to depict itself as a cooperative regional partner, participating in regional organisations and for accepting roles in regional conflict resolution and peace support, and generally refraining from pursuing narrow national interests through military strength (Ferreira \& Henk, 2005:24).

This will be outlined in greater detail in the next section.

\section{South African foreign policy and conflict resolution}

The phenomenon of ongoing and protracted conflicts in Africa has of course played an important role in setting the tone for recent and 
current-day talks on the imperative for the continent's revival, rebirth and renewal. Much of this has been encapsulated in the Mbeki African Renaissance vision - initially little more that a conceptual skeleton (Le Pere \& Van Nieuwkerk, 2002:261), but much of what is today practically embodied in the New Partnership for Africa's Development (NEPAD).

Much has been said and written in recent times about NEPAD. In its introduction NEPAD emphasises "the common vision and a firm and shared conviction" by African leaders, anchoring the programme "on the determination of Africans to extricate themselves and the continent from the malaise of underdevelopment and exclusion in a globalising world". In order to achieve these objectives, African leaders inter alia declared a joint responsibility for strengthening mechanisms for conflict prevention, management and resolution, and ensuring that they are used to restore and maintain peace (OAU, 2001). Currently, the South African policy and philosophy is heavily premised upon the key assumption that is made in NEPAD, notably that peace - and the "good governance" that allows and promotes it - is a fundamental requisite for the attraction of investment, domestic and foreign, that Africa needs. To this end, South Africa is now a state that is increasingly Africa-centred and dedicated to creating co-operative relations (Southall, 2006:23). From a national interest point of view, the South African government also made it clear that "South Africa has an obvious interest in preserving regional peace and stability in order to promote trade and development and to avoid the spillover effects of conflict in the neighbourhood" (DFA, 1999:22).

Having committed itself to regional peace and security and to the strengthening of regional security arrangements, the South African government has since the mid-1990s embarked upon a process of planning for eventualities relating to peace missions. 2 In this context the White Paper on South African Participation in International Peace Missions (hereafter White Paper) was compiled by the Department of Foreign Affairs, approved by Cabinet on 21 October 1998 and tabled in Parliament on 24 February 1999. This document should be viewed as a crucial framework and guideline for South Africa's participation in peace missions. It has a wide scope and

2 The notion peace mission is used as a generic term to include all political, diplomatic and military activities related to multinational endeavours to prevent or settle disputes in terms of the UN Charter. 
covers not only the philosophical and political aspects of involvement in peace missions, but also the practical aspects of the country's potential contributions. From a foreign policy point of view, the White Paper is certainly a document of much importance. It is possibly the most significant South African foreign policy document of the last decade, since it forced the South African government to outline its national interest and to clarify how this interest interfaced with its philosophy on conflict resolution and its general approach towards the rest of the African continent (Cilliers, 1999:10).

By issuing the White Paper, the South African government has firmly declared that as a member of the UN, South Africa has to assist the world body in its peacekeeping task. Also, in view of its economic and military strength, many observers have identified South Africa as a key player in efforts to help ensure effective peacekeeping in African conflicts. Accordingly, South Africa has experienced "a constant barrage of calls for assistance, intervention and mediation in African crises" (Vreÿ \& Esterhuyse, 2000:12). In fact, the former Secretary General of the (now defunct) OAU,3 Mr. Salim Ahmed Salim, made it clear during a visit to South Africa in December 1998 that he had been disappointed by South Africa's reluctance (at that time) to play a more active role in conflict resolution in Africa (Malan, 1999:3). Likewise, the former Director-General of Foreign Affairs, Mr. Jackie Selebi, informed the South African military in 1999 that "it is no secret that many outside our borders have been rather disappointed by the limited number of operations in which our National Defence Force has been involved in terms of peacekeeping operations" (Selebi, 1999:11).

Therefore, it is interesting to note that the White Paper starts with an opening statement to the effect that since 1994, domestic and international expectations regarding South Africa's role as a responsible and respected member of the international community have steadily grown. "These expectations have included a hope that South Africa will play a leading role in international peace missions." The White Paper also states that South Africa is committed to responsibly fulfilling its obligations under the Charters of the UN and the OAU (now AU), as well as the Southern African Development Community (SADC) Treaty (DFA, 1999:5, 23). Thus South Africa's decision-makers became fully aware of international expectations

3 The OAU was effectively replaced by the AU in July 2003 as continental organisation in Africa. 
that the country needs to play an increasingly significant politicalmilitary role in African peacekeeping requirements and international peacekeeping endeavours. In this context former Director-General Selebi stated the following in an address to the South African military (Selebi, 1999:7):

I also believe that we are jointly seeking to rapidly develop and continuously evolve in us all, as this country's foreign policy role-players, an adequate capability to engage the international community at all levels, bilateral, regional and globally. We should all seek to situate this country as an indispensable and very necessary part of the international decision-making processes, whether such matters affect international security and peace, international politics and economics, or international trade or environment ... Given the fact that the SANDF4 remains Africa's most capable and sophisticated military instrument, there is naturally great expectation that this country should increasingly be involved in peace-keeping, peacemaking and peace-enforcement operations, especially in Africa.

In more recent years, the former Deputy Minister of Defence, Ms. Nozizwe Madlala-Routledge, stated that "we are now confronted with playing an even greater role because of the progress being made in peace negotiations in the Great Lakes Region. Our country, led by President Thabo Mbeki, has taken Africa to greater heights with the launch of the African Union" (Madlala-Routledge, 2002:xi). In a public address in 2003, the Chief of the SANDF, General Siphiwe Nyanda, furthermore asserted that "South Africa, has, relatively speaking, (a) wealth of resources and capabilities to contribute (to peace missions) ... South Africa has involuntarily been thrust in a leadership role, which ultimately serves South Africa's national interest". It was furthermore stated that South Africa has just recently become widely involved in peace missions in Africa, and more deployments are on the horizon (Nyanda, 2003:1). In a similar vein, Rear Admiral Rolf Hauter, former Chief Director Strategy and Planning in the SANDF, stated that "[e]ach individual (African) country will have to decide to what extent it can contribute to the common good of the region and to the continent as a whole ... we, as South Africans, will have to come to terms with the fact that, as the biggest economy in the region, our country will always have to carry bigger responsibilities" (Hauter, 2003:2-3). Thus it should be clear that South Africa's leadership is conscious of South Africa's 
profile and international demands placed on South Africa's leadership and military capacity, and that the country needs to be responsive to calls for military contributions to peacekeeping.

This said, South Africa today regards itself as an integral part of Africa and the Government, therefore, holds the view that instability and insecurity, especially in Southern Africa, is to the detriment of the country. Thus the view is held that the country has no choice but to accept participation in multinational peacekeeping as a foreign policy priority, and that the SANDF should continue to engage in challenges of a peacekeeping nature. It should be clear from a political, security and economic perspective, that South Africa consequently maintains that an approach of close political-military involvement in regional and continental matters should be pursued. In addition, the South African leadership is conscious of South Africa's international profile and demands placed on this country's global leadership, and believes that the country needs to be responsive to calls for military contributions to peacekeeping.

Against this background Du Plessis $(2003: 106,132)$ points out that the military instrument has become more salient in South Africa's foreign policy, most notably in the form of peace support operations of varying types in support of diplomatic initiatives to resolve conflict. Practically speaking, towards the end of 2002, the SANDF clearly linked South Africa's military-strategic objectives to "promoting security", which was defined as the provision of external deployment or support to enhance security in support of decisions by the executive. In practical terms, this entails sub-regional, regional or international peace support operations (SANDF, 2002:5). While the South African Government has clearly outlined its policy guidelines on participation in peace missions, it has also moved to involve the SANDF in UN peace missions. Towards the end of 2000 an announcement was made that a limited number of South African officers would be deployed to support the internationally brokered peace process between Ethiopia and Eritrea (Van der Walt, 2001:3). Furthermore, in a significant announcement in March 2001, the South African Government stated that in compliance with the international obligations of South Africa towards the UN, the SANDF would contribute elements of specialised units to the UN mission in the DRC. This announcement was a historical development in that it paved the way for the SANDF's first substantial contribution specifically of a human resources nature - to international peace missions. In April 2002, the number of SANDF members deployed in the DRC stood at almost 150 (Anon., 2001:1). 
Soon after the South African military became involved in the DRC, the SANDF also deployed a limited number of its members to the OAU/AU mission in the Comores in April 2001 to render support to the peace process in that country (Van der Walt, 2002:1). These developments were followed by further deployments of South African troops in Burundi in October and November 2001 with a view to protecting about 150 Burundian political leaders who returned from exile to participate in that country's power-sharing transitional government. In the early stages of 2003, the number of South African troops deployed in missions of a peacekeeping-nature stood at approximately 900 SANDF servicemen and women (Nyanda, 2003:4). This figure was soon after increased to a significantly higher level, when additional SANDF members were committed to the peace process in the DRC. In August 2003, the South African Government also announced that the SANDF would play a support role in the Liberian peace process (Gibson, 2003:2).

In July 2004, the UN Security Council endorsed Resolution 1556, which provided for the deployment of a protection force by the AU in war-ravaged Darfur, Sudan to monitor a cease-fire agreement concluded on 8 April 2004 between the Khartoum government and two rebel groups. This paved the way for the $A U$ to approve the African Mission in Sudan (AMIS) on 28 May 2005 - which has arguably become the most important challenge for $A U$ peacekeeping endeavours in recent times. As part of AU efforts to resolve the crisis in the Darfur region, the SANDF was requested for troop contributions. The "AMIS Plan" provided for 8 Battalions: 3 from Nigeria, 3 from Rwanda, 1 from Senegal and 1 from South Africa to be deployed from 30 September 2005 (Boshoff, 2005). However, AMIS never really succeeded in bringing security to the war-torn Darfur province, and media coverage on the AU became progressively critical. In September 2006, a senior SANDF officer announced that the South African government has decided to supplement the figure of 700 South African AMIS staff members with an additional 647 members (Pelser, 2006:7) - thereby clearly signalling South Africa's firm political commitment to peace and security on the African continent.

Finally, in terms of an agreement between the South African government and that of Côte d'Ivoire (Ivory Coast), military personnel from the SANDF were deployed to facilitate efforts in resolving the conflict in Côte d'Ivoire. In March 2006, SANDF contributions to conflict resolution and peacekeeping in Africa's conflict-stricken areas have risen to a figure of 4000 (Stead, 
$2006: 1,3)$. All of this implies that the minor initial deployments have developed into large scale and diverse responsibilities for South African political and military functionaries.

"Peace missions are by nature complex and multi-faceted ... This requires a mature and realistic approach to understanding and preparing for these commitments" (Stead, 2006:3). All of this seems to underscore the importance and relevance of peace studies as a field of scholarly inquiry that is aimed at understanding the causes of armed conflict and war by systematic analyses of the historical experiences of phenomena in this regard, and how they can effectively be dealt with. Nowhere is this more relevant than in the African context, and South African tertiary institutions certainly has a significant role to play in this regard.

\section{Appraisal and conclusion}

The growth of peace studies programmes in many parts of the world indicates a concern for the future of the international community and the devastating effects of armed conflict and political strife. Faculties at various tertiary institutions attempt to use their skills to educate students about the causes of war, while pointing out various alternatives to violent behaviour. Also, worldwide, graduates in the field of peace studies engage in peacemaking careers in the areas of arms control, foreign policy, human rights, environmental protection, law, journalism, government, international organisations, and so forth (Harris, Fink \& Rank, 2004).

However, this does not imply that the subject of peace studies is not controversial and sometimes criticised. Steinberg (2003:1), for instance, argues that important dimensions of the literature based on Realist perspectives concerning the nature of violence and the use of force to manage conflicts, are often ignored, while Idealist models tend to be presented uncritically. This means that Realist theories of explaining and understanding international events are often totally discarded, or in some cases, rejected on ideological grounds. As a result, students in peace studies rarely encounter the analyses of prominent Realist scholars. Sometimes distorted academic frameworks are also used to impose a particular definition of "the just society" and dictate who should be empowered and who should be ostracised. For example, this problem has been particularly acute in consideration of the Arab-Israeli conflict in the context of particular peace studies programmes. In general, this dispute has been turned into a situation where Israel is often portrayed as the more powerful or dominant party, while the 
Palestinians are depicted as powerless victims of historic injustice. This implies that there are ideologically distorted curricula, including reading lists, video material and speakers who present models and analyses of conflicts, damaging the integrity of peace studies as an academic endeavour. Furthermore, the Idealistic approach to peace studies - including dimensions such as reconciliation, apology, rebalancing of power relationships, and historical justice - are often based on inherently subjective and often highly one-sided political judgments. In some instances, the use of force or coercive measures to prevent or resolve conflict (in terms of Chapter VII of the UN Charter) is rejected on ideological grounds. To this end, some peace studies programmes sometimes go beyond thorough and, as far as possible, objective and honest appraisal and advocacy (Steinberg, 2004:4, 5, 6).

Against this background, Steinberg (2004:11) advocates for specific parameters to be applied to the conduct of peace studies, including the following dimensions:

- Peace studies as a scholarly endeavour should seek to encourage reading lists, lectures and related activities that fully present the different ideologically based depictions and paradigms regarding the sources and manifestation of conflict. In particular, the literature presenting Realist perspectives on conflict should also be considered in the broad free market place of ideas.

- In presenting the details of any conflict, it is important that academic standards of objectivity are heeded.

- Academic programmes in general, and peace studies in particular, should avoid political advocacy or any actions that would constitute participation in any conflict, taking sides, or promoting the claims of any of the parties.

Peace studies in the South African and broader African context are certainly of great significance and importance. Given Africa's peculiar challenges and immense problems the ultimate goal of peace studies in the university context should be to produce practical and useful scholarship on how to create a more just and peaceful continent. Moreover, given South Africa's special and most significant political-military role and leadership on the African continent, South African universities - specifically within the social sciences - cannot ignore the need for producing students with knowledge, skills and an intellectual capacity on issues pertaining to 
a (much needed) resolution of conflicts on the African continent. After all, the SANDF's progressive involvement in peace missions in recent years is far more than an issue of mere military concern. It is an issue of great political importance and significance. Conflict resolution and peacekeeping today are clearly at the centre of South Africa's foreign policy outlook towards the African continent and a pivotal part of NEPAD as Africa's political roadmap to a future of development and progress. This said, it needs to be stated that South African universities - at least the majority of them - have not yet engaged in dedicated teaching in peace studies and issues relating to understanding the causes, dynamics and effects of conflict, and to promote through this understanding an addressing of the conflict through mechanisms of conflict resolution and peace building. Mostly, peace studies form fairly small - sometimes even minor - sub-units of political sciences curricula, specifically International Relations and African studies curricula.

In the final analysis, scholarship in peace studies requires empirical accounts of the causes of war, violence, and injustice; and practical understandings of how to prevent and ameliorate harmful social conditions. This subject matter raises many basic but pressing questions: What is peace? What is conflict? How can one be encouraged and the other avoided? In this regard, students should be exposed to a rich and comprehensive literature on the search for international peace and security, of how to deal with and address the causes of large-scale conflict and violence, of how it could be curtailed and resolved - a literature which informs and underpins scholarly discussions and research in many centres and places of education, training and peacemaking. After all, the gripping and devastating violence that manifested in areas such as Cambodia, Bosnia, Kosovo, and on our own African continent in places such as Liberia, Sierra Leone, Sudan, Burundi, Rwanda, the DRC, Somalia, Angola, the Comoros and many other conflict-stricken areas warrant scholarly attention from South African and fellow African scholars.

Against this background one has to agree with the contention of Kirsten (2006:12) that "... the contribution of institutions of higher education in processes of peace can never be overestimated. The leadership material that universities produce and the added value of that to productive and peaceful societies are of major importance". This is generally true, but even more so in the case of Africa which remains in a state of deep and persistent malaise. After all, it is still by far the world's least developed continent economically, and most conflict-prone continent politically. 


\section{List of references}

ACCORD

see AFRICAN CENTRE FOR THE CONSTRUCTIVE RESOLUTION OF DISPUTES

AFRICAN CENTRE FOR THE CONSTRUCTIVE RESOLUTION OF DISPUTES. 2006a. Peace and security. www.accord.org.za/ps/intro.htm Date of access: 8 May 2006.

AFRICAN CENTRE FOR THE CONSTRUCTIVE RESOLUTION OF DISPUTES. 2006b. Who are we? www.accord.org.za/web/home.htm Date of access: 8 May 2006.

ANON. 2001. Deployment of specialised units of the SANDF to the DRC. Department of Defence Bulletin, 27 March 2001.

ANON. 2006. Peace studies programs. www.quitspaces.co/peacestudies.html Date of access: 4 May 2006.

BOSHOFF, H. 2005. The African Union Mission in Sudan. African Security Review, 14(3):1-4. www.iss.co.za/index.php?link_id=3\&slink_id=1898\& link_type=12\&slink_type=12tmpl_id=3 Date of access: 28 Aug. 2006 .

CILLIERS, J. 1999. An emerging South African foreign policy identity. ISS Papers, 39:1-15.

CLAPHAM, C. 1998. The United Nations and peacekeeping in Africa. Paper delivered at a conference on International Peace and Security: The African Experience, SA Military Academy, Saldanha, 21-23 September 1998.

DE CONING, C. 2004. Coherence and integration in the planning, implementation and evaluation of complex peace-building operations. Conflict Trends, 1:41-48.

DEPARTMENT OF FOREIGN AFFAIRS. 1999. White Paper on South African participation in international peace missions. Government Gazette, Notice 2216 of 1999, 4 October.

DFA

see DEPARTMENT OF FOREIGN AFFAIRS

DU PLESSIS, A. 2003. The military instrument in South Africa's foreign policy: a preliminary exploration. Strategic Review for Southern Africa, 25(2):106138.

EVANS, G. \& NEWNHAM, J. 1998. The Penguin dictionary of international relations. London: Penguin Books.

FERREIRA, R. \& HENK, D. 2005. Military implications of human security: the case of South Africa. Paper delivered at the 45th anniversary biennial international conference of the Inter-University Seminar on Armed Forces \& Society, Palmer House Hilton Hotel, Chicago, 21 October.

FINLEY, L.L. 2003. How can I teach peace when the book only covers war? Online Journal of Peace and Conflict Resolution, 5(1):150-165.

GIBSON, E. 2003. Parlement moet ja sê vir ontplooiing. ("Parliament must say yes to deployment"). Die Burger: 5, 13 Aug.

HARRIS, I.M., FISK, L.J. \& RANK, C. 1998. A portrait of university peace studies in North America and Western Europe at the end of the millennium. International Journal of Peace Studies, 3(1):1-19. www.gmu.edu/ academic/jips/vol3_1/Harris.htm Date of access: 4 May 2006. 
HAUTER, R. 2003. The challenges of military strategy. Paper presented at a symposium on Strategic Challenges for South Africa, organised by the Centre for Military Studies, University of Stellenbosch and the Institute for Strategic Studies, University of Pretoria, Pretoria, 27 February.

HOLSTI, K.J. 1983. International politics: a framework for analysis. 4th edition. Englewood Cliffs: Prentice Hall.

INSTITUTE FOR SECURITY STUDIES. 2006a. Approach and focus. www.iss.co.za/about/app_focus.html Date of access: 8 May 2006.

INSTITUTE FOR SECURITY STUDIES 2006b. Funders and donors. www.iss.co.za/about/Funders.html Date of access: 8 May 2006.

ISS

see INSTITUTE FOR SECURITY STUDIES

INTERNATIONAL PEACE RESEARCH ASSOCIATION 2006. A message from the Secretary General of the International Peace Research Association. http://soc.kuleuven.be/pol/ipra/index.html Date of access: 25 Apr. 2006.

\section{IPRA}

see INTERNATIONAL PEACE RESEARCH ASSOCIATION

IRIN (UN Office for the Coordination of Humanitarian Affairs). 2006. Comores: IRIN briefing on separatist crisis. www.irinnews.org/S_report.asp? ReportID=13397\&SelectRegion=Southern_Africa Date of access: 22 Sept. 2006.

JACKSON, R. 2002. Violent internal conflict and the African state: towards a framework of analysis. Journal of Contemporary African Studies, 20(1):2952.

KIRSTEN, J. 2006. Africa - a continent in need of peace. Paper delivered at a conference, Voices of Africa - Voices of Peace, Potchefstroom campus of the North-West University, 6-8 March.

LAWSON, S. 2003. International relations. Cambridge: Polity.

LE BILLON, P. 2006. Resource wealth and Angola's uncivil wars. (In Arnson, C.J. \& Zartman, I.W., eds. Rethinking the economics of war: the intersection of need, creed, and greed. Washington: Wilson. p. 107-139.)

LE PERE, G. \& VAN NIEUWKERK, A. 2002. The evolution of South Africa's foreign policy, 1994-2000. (In McGowan, P.J. \& Nel, P., eds. Power, wealth and global equity: an international relations textbook for Africa. Cape Town: University of Cape Town Press. p. 248-266.)

LODGE, T. 1998. Armed conflict in Africa since the Cold War. Paper delivered at a conference on International Peace and Security: The African Experience, SA Military Academy, Saldanha, 21-23 September 1998.

MADLALA-ROUTLEDGE, N. 2002. Foreword by the Honourable Ms. N.C. Madlala-Routledge, Deputy Minister of Defence. South African Department of Defence. Annual Report, 2001/2002.

MALAN, M. 1999. Renaissance peacekeeping - a South African solution to conflict in the DRC. ISS Papers: 1-10, 37.

N'DIAYE, B. 2004. Not a miracle after all ... Côte d'Ivoire's downfall: flawed civil-military relations and missed opportunities. Scientia Militaria, 33(1): 89-118.

NEL, P. 1999. Theories of international relations. (In Nel, P. \& McGowan, P.J., eds. Power, wealth and global order: an international relations textbook for Africa. Cape Town: University of Cape Town Press. p. 47-69.) 
NORTH-WEST UNIVERSITY. 2006. Peace conference on PUK campus: Voices of Africa - Voices of Peace. www.puk.ac.za/opencms/export/PUK/ NWU html/nuus/nuus246_ee.html Date of access: 15 Mar. 2006.

see NORTH-WEST UNIVERSITY

NYANDA, S. 2003. The South African National Defence Force and peace missions in Africa. Paper presented at a conference under the auspices of the African Centre for the Constructive Resolution of Disputes, the Centre for International Political Studies and the Pretoria branch of the SA OAU Institute for International Affairs, University of Pretoria, 27 February 2003.

SEe ORGANISATION OF AFRICAN UNITY

OLONISAKIN, F. 2002. Conflict and conflict resolution in Africa. (In McGowan, P.J. \& Nel, P., eds. Power, wealth and global equity: an international relations textbook for Africa. Cape Town: University of Cape Town Press. p. 231-247.)

ORGANISATION OF AFRICAN UNITY. 2001. The new partnership for Africa's development (NEPAD). Adopted at the 37th Summit of the OAU in July 2001.

PELSER, W. 2006. SA wil vredesmag in Darfoer byna verdubbel. Die Burger: 7 , SANDF 21 Sept.

see SOUTH AFRICAN NATIONAL DEFENCE FORCE

SCHRAEDER, P. 2004. African politics and society: a mosaic in transformation. 2nd ed. Belmont: Thompson.

SELEBI, J. 1999. The role of the Department of Defence in the promotion of South Africa's foreign policy, especially in Africa. Presentation to the SA SIPRI National Defence College, Thaba Tshwane, 10 March 1999.

see STOCKHOLM INTERNATIONAL PEACE RESEARCH INSTITUTE

SOUTH AFRICAN NATIONAL DEFENCE FORCE. 2002. South African military strategy. Pretoria: 1 Military Printing Regiment.

SOUTHALL, R. 2006. Introduction. (In Southall, R., ed. South Africa's role in conflict resolution and peacekeeping in Africa. Cape Town: HSRC. p. 126.)

STEAD, S.K. 2006. The SANDF contribution to peace support operations in Africa. Paper delivered at a conference on Peacekeeping, Reconstruction and Stability Operations in Africa, organised by the International Quality and Productivity Centre, Gallagher Estate, Midrand, 28-31 March 2006.

STEINBERG, G.M. 2004. The thin line between peace education and political advocacy. Paper based on a presentation at the UNESCO conference on education towards a culture of peace, Bar Ilan University, December 2003. (Revised 22 February 2004.)

STOCKHOLM INTERNATIONAL PEACE RESEARCH INSTITUTE. 2003. SIPRI. www.sipri.se Date of access:10 Jul. 2006.

UN

see UNITED NATIONS

UNITED NATIONS. Department of Public Information. 2006. "Ethiopia and Eritrea - UNMEE - Background". http://www.un.org/Depts/dpko/missions/ unmee/ background.html Date of access: 22 Sept. 2006. 
UNIVERSITY OF BRADFORD. 2006. Postgraduate courses 2006 entry. www.brad.ac.uk/university/pgpros/peace.php Date of access: 4 May 2006.

VAN DER WALT, J. 2001. Information on recent and current external force employments. Facsimile from Col. Van der Walt (Senior Staff Officer: External Operations, Chief of Joint Operations Formation, SA National Defence Force) to the author, 24 June 2002.

VREŸ, F. \& ESTERHUYSE, A. 2000. South Africa and Southern Africa: isolationist or regional conflict manager. Conflict and Development Watch, 2(1):8-12.

WALLENSTEEN, P. 2002. Understanding conflict resolution: war, peace and the global system. London: Sage.

\section{Key concepts:}

causes of armed conflict

conflict in Africa

conflict resolution

peace studies

peacekeeping

\section{Kernbegrippe:}

konflik in Afrika

konflikresolusie

oorsake van gewapende konflik

vredesbewaring

vredestudies 